\title{
波の到来方向に基づく宅地における局所的軟弱地盤位置の同定 IDENTIFICATION OF LOCAL SOFT GROUND POSITION IN HOUSING SITE BASED ON ARRIVAL WAVE ANGLE
}

\author{
田村修次*1, 外山直樹*2 \\ Shuji TAMURA and Naoki UYAMA
}

\begin{abstract}
A method is presented for identification of local soft ground position based on measurement of the angle between arrival wave and a vibration source. Vertical ground motion is measured using a circular array of six sensors. The angle between the arrival wave and the source can be determined, based on F-k spectrum analysis of the data. To examine the validity of the proposed method, field investigations were performed. It is shown that (1) The arrival wave angles tend to fluctuate wildly in case that local soft ground locates between the sensor array and the source and the wavelength is about 1.5 times the soft ground depth; (2) The arrival wave angles tend to point in the direction of the source in case that ground between the sensor array and the source is uniform.
\end{abstract}

Keywords: Local soft ground, Arrival wave angle, Geophysical exploration, Housing site, Array observation 局所的軟弱地盤、波の到来方向、物理探查、宅地、アレイ観測

\section{1.はじめに}

現在、欠陥住宅が社会問題となっている。（財）住宅リフォー ム・紛争処理センターによると、相談件数の多い不具合部位は1 位：床、2位：外壁、3位：内壁、4位：開口部建具である1)。基礎の 相談件数は8位、地盤の相談件数は11位であり、基磷・地盤の相談 件数は比較的少ない。ただし、床の傾斜、外壁や内壁の亀裂、開口 部建具の不具合は、地盤の不同沈下や基䃈工事の不備に起因寸る場 合が多い。そのため、久宿住宅の $72 \%$ 地盤の不同沈下および基礎 工事の不備に起因しているという報告2)もなされている。不同沈下 の要因としては、例えば軟弱な粘性土、盛土・埋立て土、砂地盤の 液状化（地震時）がある。また、それ以外に局所的な地盤の問題、 例えば「ゴミ、ガラ、大木の根を掘り取った跡、池を埋めた跡、地 中のコンクリートの巨塊など」も不同沈下の要因として挙げられて いる ${ }^{3)}$ 。建設後に基礎・地盤でトラブルが発生すると、その対策に 莫大な費用がかかる。したがって、事前の地盤調查・対策が重要で ある。

宅地の地盤調查法として、スウェーデン式サウンディング試験 （S S 試験）が一般的に行われている。S S 試験は、建物の対角線 上の 3 点または四隅で行うことが多い。また、レイリー波の分散性 に着目した表面波探查 $\left.{ }^{4)}, 5\right)$ も、宅地レベルの地盤調査や液状化危険
度の予測(6)に適用可能である。また、センサーを直線状に多数設置 することで、2次元断面を推定する手法も提案”されている。

軟弱地盤等が敷地全体に存在する場合、既往の地艋調查でその把 握が可能である。ただし、既往の地盤調查は、敷地平面における 「点（1次元）」または「線（2次元）」が対象である。そのため、 既往の地盤調查では、敷地に伏在している局所的軟弱地盤を把握で きないケースがある。

敷地全体における地盤の不均一性を簡便に評価し、S S 試験等を 行う場所を選定すれば、局所的軟弱地盤等を把握できる。また、そ れに基づいて適切な対策をすることで、戸建住宅の基礎・地盤のト ラブルを减少させることが可能と考えられる。そこで本研究では、 地盤の不連続面で波が屈折する性質を利用し、局所的軟弱地盤の位 置を簡便に同定する方法を提案する。

\section{2. 局所的軟弱地盤が波の到来方向に及ぼす影響}

\section{1. 波の到来方向と地盤条件}

図 1 は、地盤条件と波の伝播を模式図で示している。均一な地盤で は、図 1 (a)に示すように加振源から発生した波は、直線的に観測点 に到達する。この場合、観測地点における波の到来方向と実際の加振 方向は一致する。それに対し、加振源と観測点で地盤が異なる場合、
*1 京都大学防災研究所 助教授. 博士 (工学)

*2 大林組 修士 (王学)

(元 信州大学 大学院生)
Assoc. Prof., DPRI, Kyoto University, Dr. Eng.

Obayashi Corp., M. Eng.

(Former Graduate Student, Shinshu University) 


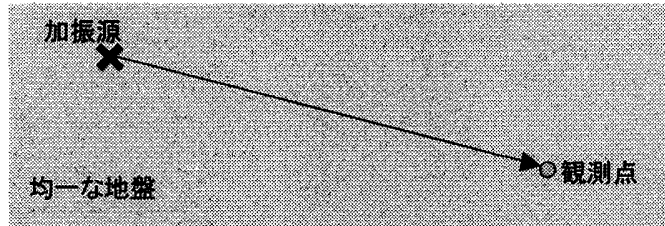

（a）均一な地盤における波の伝播

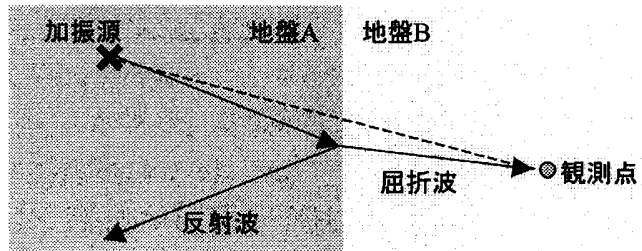

（b）不連続面がある地盤における波の伝播

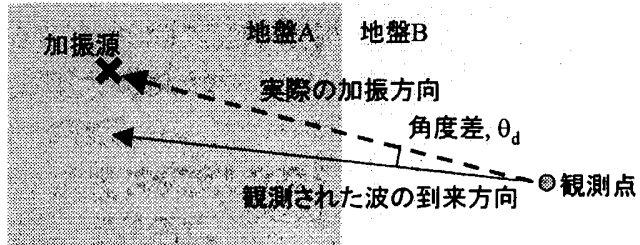

（c）不連続面がある地盤における加振方向と波の到来方向

図 1 地盤条件と波の伝播（模式㘠）

図 1 (b)に示すように地盤の境界面で反射波、屈折波が発生する。観 測点では屈折波を計測するため、図 1 (c) に示すように観測される波 の到来方向と寒際の加振方向は異なると考えられる。以上から、地表 面の 1 点で人工的に加振し、実際の加振方向と波の到来方向の角度 差を評価すれば、加振源と観測点間における地盤の不連続性を把握 できると考えられる。

\section{2 アレイ観測による波の到来方向の推定}

波の到来方向は、微動計を用いてアレイ観測を行い、F-kスペクト ル解析多することで推定可能と考えられる。その検証実験を、信州大 学工学部グラウンド (長野市) で行った。試験サイトにおける表層地 盤のS 波速度構造を図 2 に示す。S波速度構造は、アレイ観測で計測 された分散曲線の逆解析によるものである。地表付近のS 波速度は $100 \sim 120 \mathrm{~m} / \mathrm{s}$ であるが、深度 $2.7 \mathrm{~m}$ 程度より染いところの $\mathrm{S}$ 波速度は $650 \mathrm{~m} / \mathrm{s}$ 程度である。

アレイ観測による波の到来方向の妥当性を、図3に示すアレイ配置 と加振源で行った。アレイ半径を0.3mとし、4.5Hz鉛直成分微動計（物探 サービス社製）を円周上に5点、中心に 1 点設置した。加振は人の跳踓と し、中心センサーから $5 \mathrm{~m}$ 離れた地点で行った。方向は真北を $0^{\circ}$ と し、加振方向は観測アレイの真南 $\left(180^{\circ}\right)$ とした。以降、角度は時計回りを 正とする。観測された波形はローパスフィルター150Htを通して、サンプリン グ周波数1000HをでA1変換し、ノートパソコンに記録した。

加振なしの場合と加振ありの場合における鉛直成分フーリェスペ クトルを図 4 に示す。加振なしの場合、卓越周波数は $19 \mathrm{~Hz}$ である。一 方、加振ありの場合、卓越周波数は30Hz付近である。加振なし、加振 ありのスペクトルの差から、人の跳躍で $10 〜 100 \mathrm{~Hz}$ 程度の波が励起さ れることがわかる。

$\mathrm{F}-\mathrm{k}$ スペクトル解析で得られた波長と波の到来方向の関係を図 5

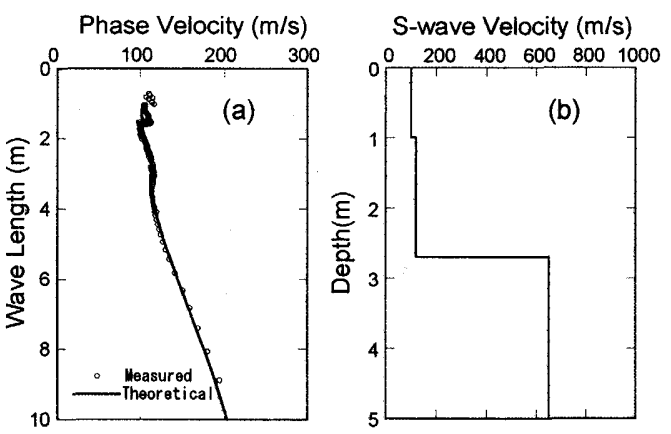

図 2 試験サイトにおける分散曲線と逆解析で得られた $\mathrm{S}$ 波速度構造

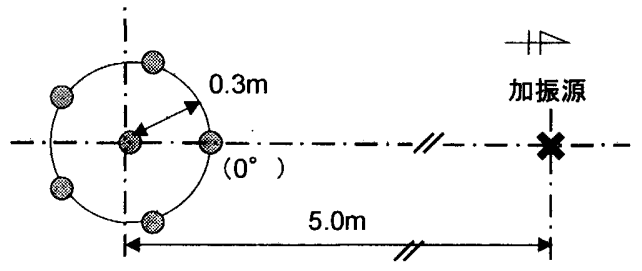

図 3 アレイ配置と加振源

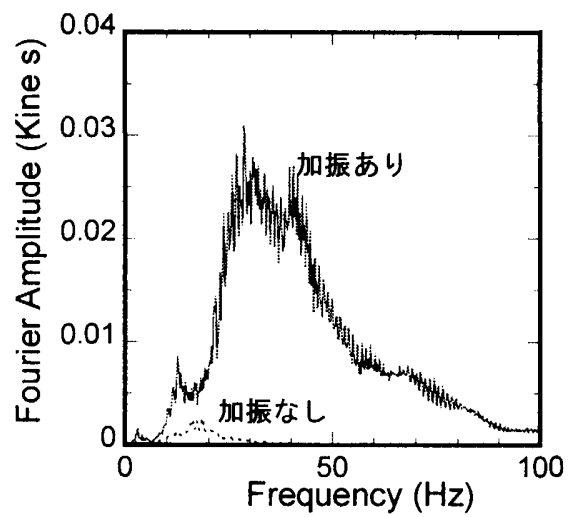

図 4 加振の有無とフーリエスペクトル（中心センサー）

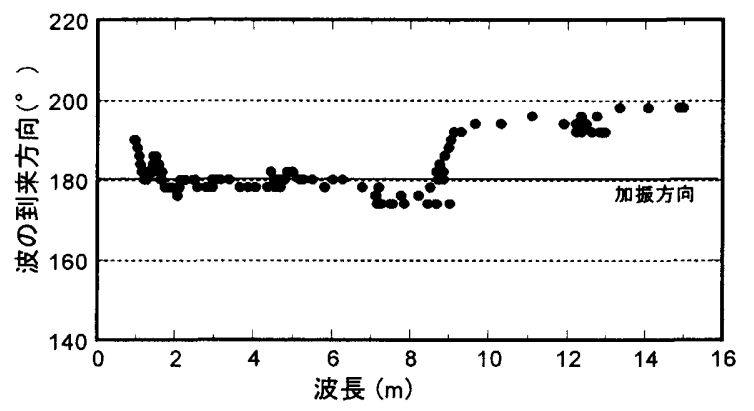

図 5 波長と波の到来方向

に示す。な㧍、センサーの周波数特性を考虑して、80Hz以下の周波数 を対象とした。波の到来方向は、波長 $6 \mathrm{~m}$ 程度まで実際の加振方向で ある $180^{\circ}$ に近い值を示している。波長 $6 \mathrm{~m}$ 程度から波の到来方向の 精度がやや悪くなり、波長 $8 \mathrm{~m}$ で波の到来方向が加振方向と $20^{\circ}$ 程度 異なる。以上から、本ケースでは波長 $6 \mathrm{~m}$ までを検討対象とする。

\section{3 波の到来方向と局所的軟弱地盤}

局所的軟弱地盤が波の到来方向に及ぼす影響を検討するため、信 州大学工学部グラウンドにおいて、図 6 に示す観測アレイ、局所的 軟弱地艋および加振点の位置関係で実験（Case A)を行った。観測ア 


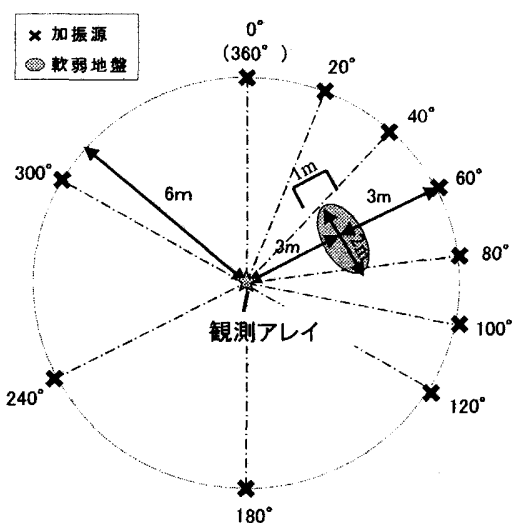

図 6 観測アレイと局所的軟弱地盤および加振点(Case A)

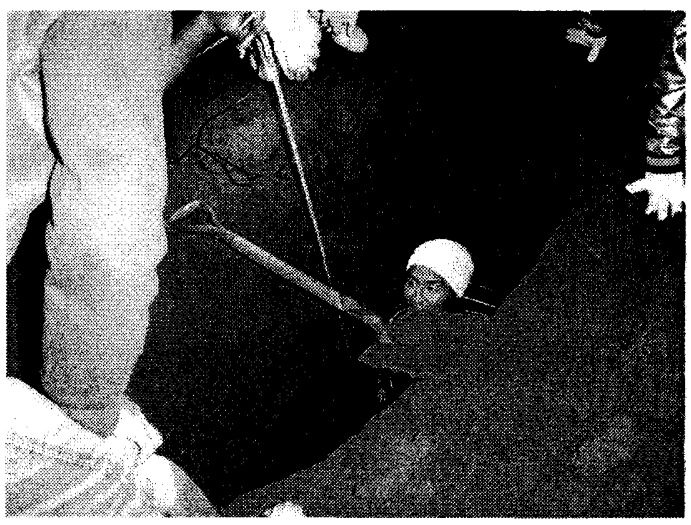

写真 1 局所的軟弱地盤の形状（埋め戻す前）
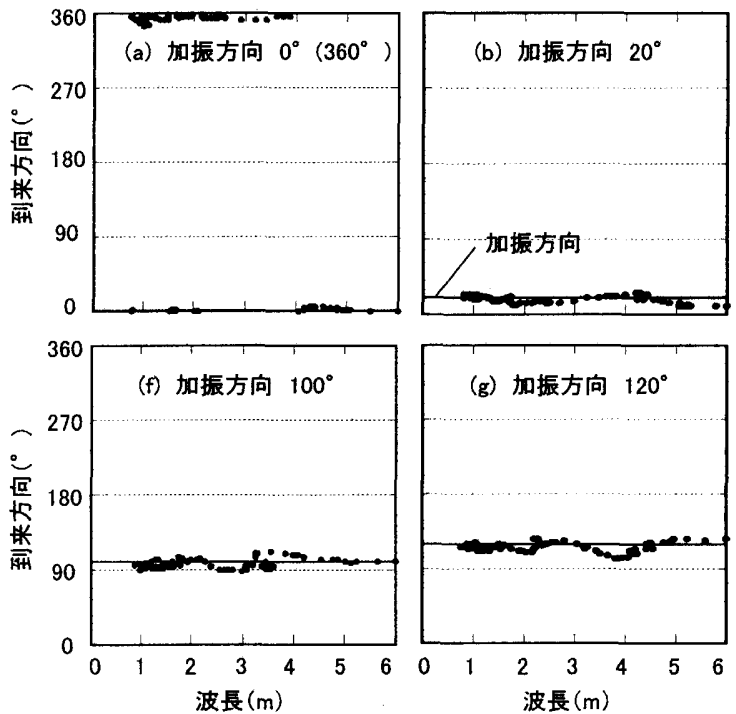

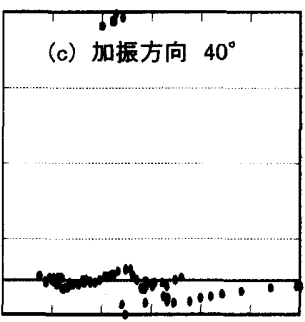

(h) 加振方向 $180^{\circ}$

図 7 波長と波の到来方向（Case A)
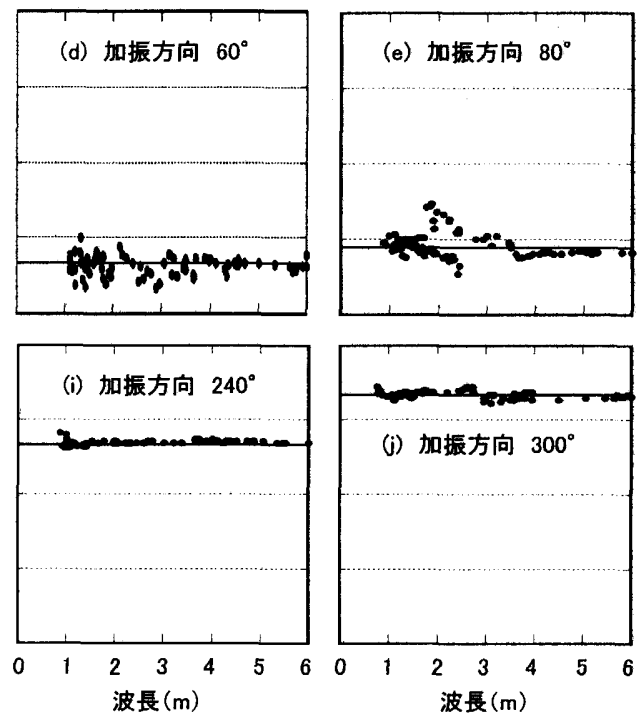

波長 (m)

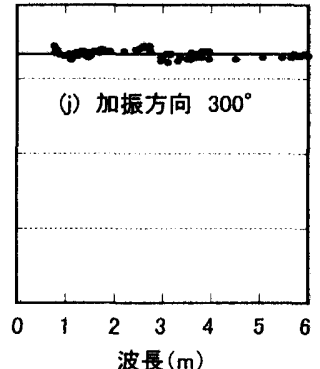

波長 $(m)$
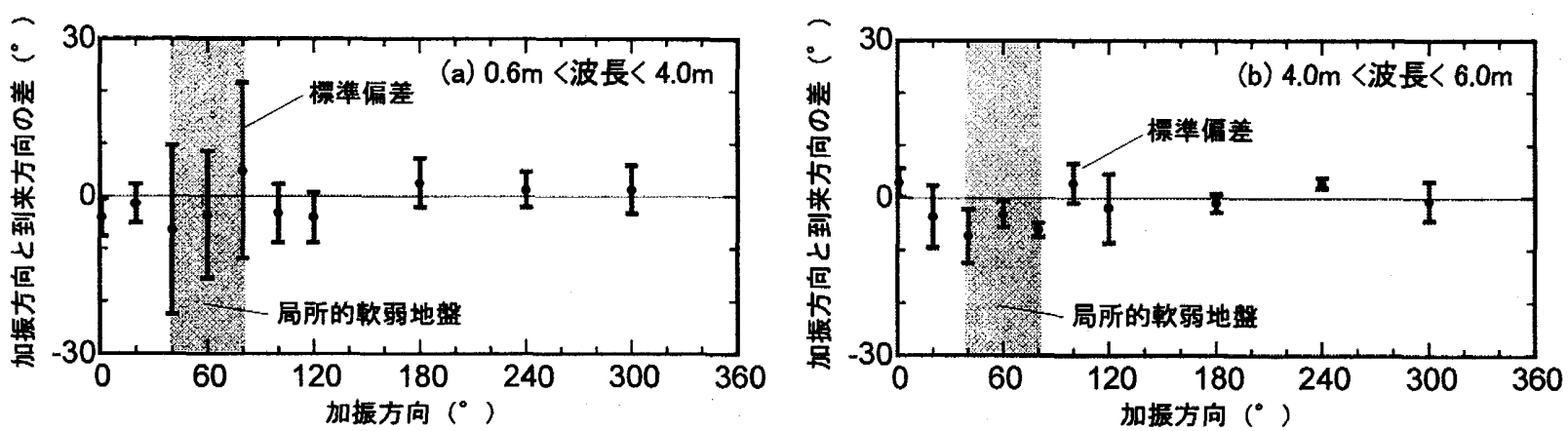

図 8 各加振点における加振方向と波の到来方向の角度差（Case A)

レイは、半径 $0.3 \mathrm{~m}$ の五角形アレイとし、 $4.5 \mathrm{~Hz}$ 鉛直成分微動計を円周 上に 5 点、中心に 1 点設置した。局所的軟弱地盤は、写真 1 に示すよう に幅 $2 \mathrm{~m} 、$ 奥行き $1 \mathrm{~m} 、$ 深さ $1.3 \mathrm{~m}$ の穴を掘り、土を埋め戻して作成し た。板吒き法で得られた局所的軟弱地盤のS波速度は $60 \mathrm{~m} / \mathrm{s}$ 程度で あった。局所的軟弱地盤は観測アレイから $3 \mathrm{~m}$ 程度、加振方向 $40^{\circ}$ 〜 80 のところに位置する。加振は人の跳躍とし、観測アレイを中 心とする半径 $6 \mathrm{~m}$ の円周上で、加振方向 $0 \sim 120^{\circ}$ で $20^{\circ}$ 間隔、加振 方向 $120 \sim 360^{\circ}$ で $60^{\circ}$ 間隔で行った。

各加振点における波の到来方向と波長の関係を図 7 に示す。局所 的軟弱地盤が存在しない方向 $\left(0^{\circ} ， 20^{\circ} ， 100^{\circ} \sim 300^{\circ}\right)$ から加
振した場合、波長によらず波の到来方向は加振方向と概ね一致して いる。それに対し、局所的軟弱地盤が存在する方向 $\left(40^{\circ} 、 60^{\circ}\right.$ 、 $80^{\circ}$ ）から加振した場合、到来方向は一定せずにばらつく。特に加 振方向 $40^{\circ}$ および $80^{\circ}$ における波の到来方向のばらつきは大きい。 すなわち、局所的軟弱地盤に対して直交方向から波が入射するケー スよりも、ある程度の角度をもって波が入射するケースの方が、波 の到来方向のばらつきは大きい。なお、波の到来方向は、短い波長 で大きくばらつく傾向を示す。

到来方向のばらつく波長を検討するために、図 8 に各加振点にお ける加振方向と波の到来方向の角度差の平均值および標淮偏差を、 
波長 $0.6 \sim 4.0 \mathrm{~m}$ よび波長 $4.0 \sim 6.0 \mathrm{~m}$ について示す。波長 $0.6 \sim 4.0 \mathrm{~m}$ の場合、局所的軟弱地盤の存在する加振方向 $\left(40 \sim 80^{\circ}\right)$ において 標淮偏差が大きい。それに対し、波長 $4.0 \mathrm{~m} \sim 6.0 \mathrm{~m}$ の場合、どの加振 方向においても標準偏差が比較的小さい。すなわち、波長がある程 度大きくなると、局所的軟弱地盤が波の到来方向に及ぼす影響は小 さくなると考えられる。

局所的軟弱地盤によって波の到来方向がばらついた要因を検討す るため、図 9 に局所的軟弱地盤を通る波線を模式図で示す。加振源 から発生した波は、局所的軟弱地盤に入る時および出る時に屈折す る。局所的軟弱地盤内で反射波も発生することを考虑すると、波は 極めて複雑な波線で観測アレイを通過すると考えられる。一方、Fkスペクトル解析は、観測アレイを通過する波を平面波と仮定して いる。このため、F-kスペクトル解析で算定した波の到来方向がば らついたと考えられる。3次元の局所的軟弱地盤を通る波動伝播は 複雑な現象であり、今後、波の到来方向がばらつく要因を検郡する 予定である。

\section{4 局所的軟弱地盤の位置の同定}

前節の倹討から、観測アレイを中心とする円周上で加振をするこ

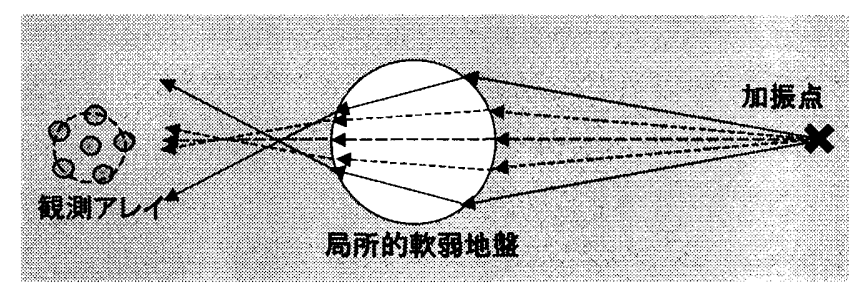

図 9 局所的軟弱地盤と波線（模式図）

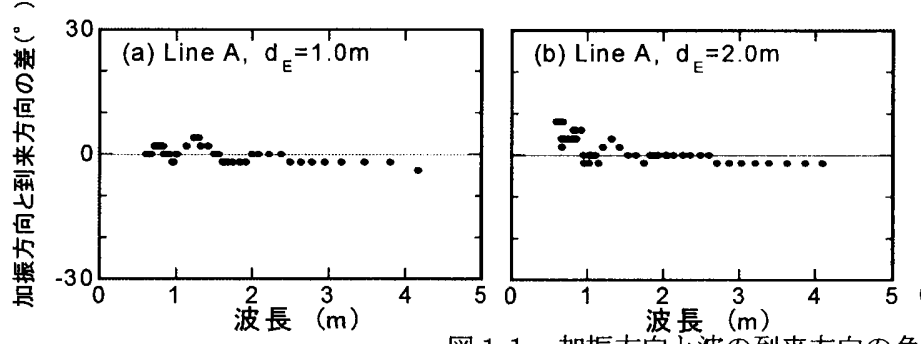

図 11 加振方向と波の到来方向の角度差と波長 (Line A, Case B)
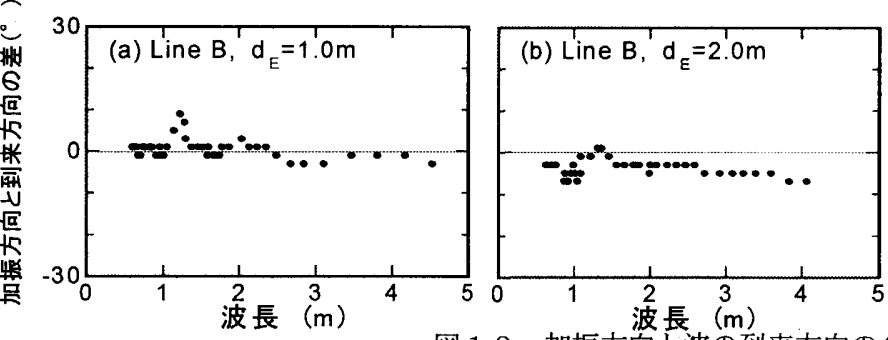

図 12 加振方向と波の到来方向の角度差と波長 (Line B, Case B)
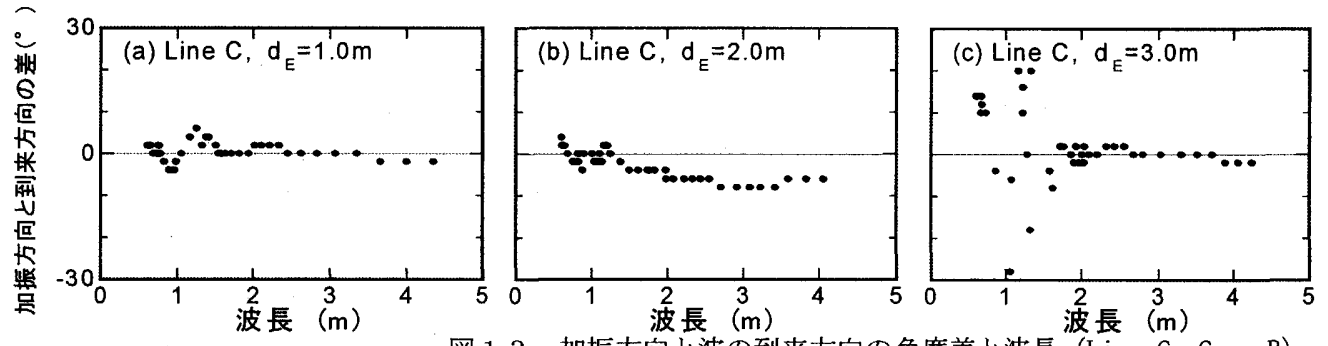

図 13 加振方向と波の到来方向の角度差と波長（Line C, Case B)
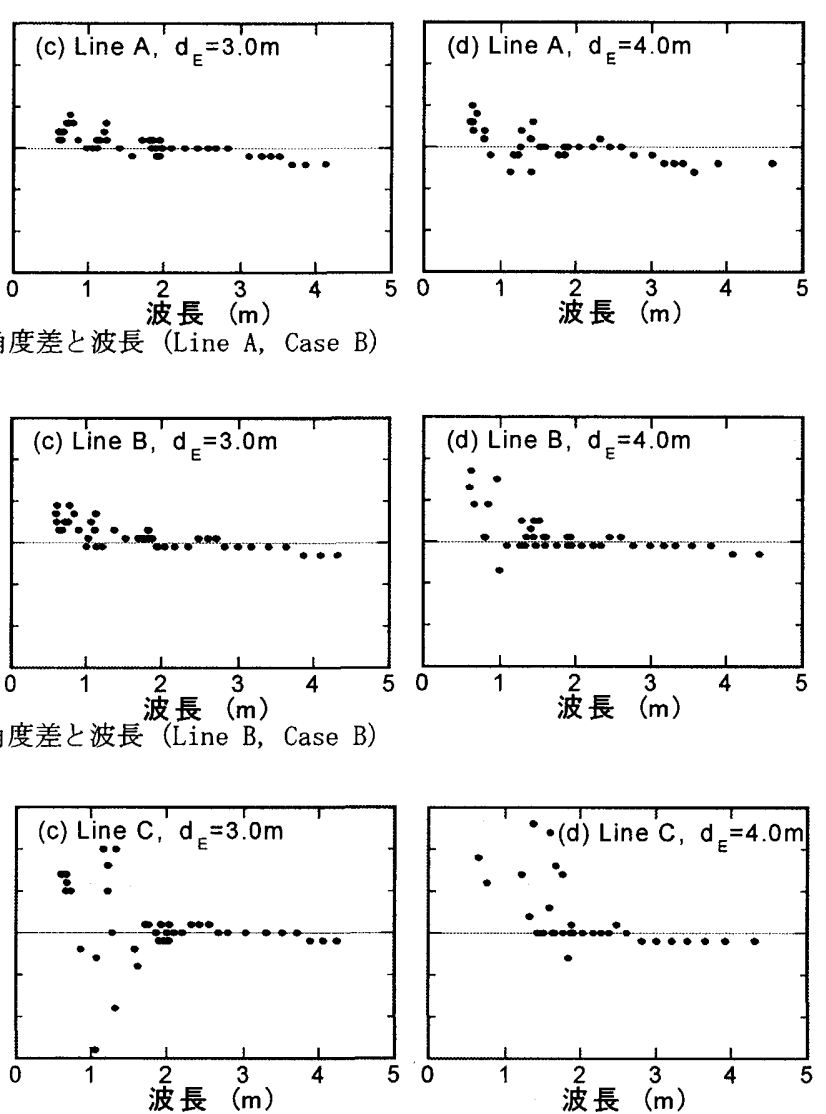

とで、局所的軟弱地盤の存在する方向を把握できることが分った。 らに波の到来方向のばらついた加振点と観測アレイの間で加振す れば、局所的軟弱地盤の位置を絞ることができると考えられる。そ 当性を検討するために、信州大学工学部グラウンドにおいて、 実験 (Case B) を行った。局所的軟弱地船は、直径 $0.7 \mathrm{~m} 、$ 深さ0.7mの円 筒状の穴を掘り、土を埋め戻して作成した。局所的軟弱地盤は、観 的軟弱地盤の深度が浅く、Case Aよりも高い周波数の波を対象にす るためである。加振は人の跳躍とし、Line A，B，Cで行った。加振 距離 $\left(\mathrm{d}_{\mathrm{E}}\right)$ は $1.0 \mathrm{~m}$ から $4.0 \mathrm{~m}$ まで $0.5 \mathrm{~m}$ 間隔とした。観測された波形は、 $30 \mathrm{~Hz}$ 以上とした。そのため、対象波長は最大 $4 \sim 5 \mathrm{~m}$ 程度である。 向の関係を図11〜13に示す。加振距離1.0mでは、Lineによらず加振 方向と波の到来方向が概ね一致する。加振距離2.0mでは、Line A, B,Cともに局所的軟弱地盤上で加振しているにもかかわらず、到来

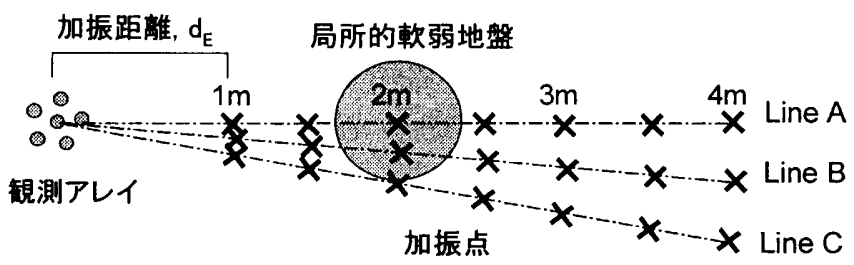

図 10 観測アレイと局所的軟弱地盤および加振点（Case B) 

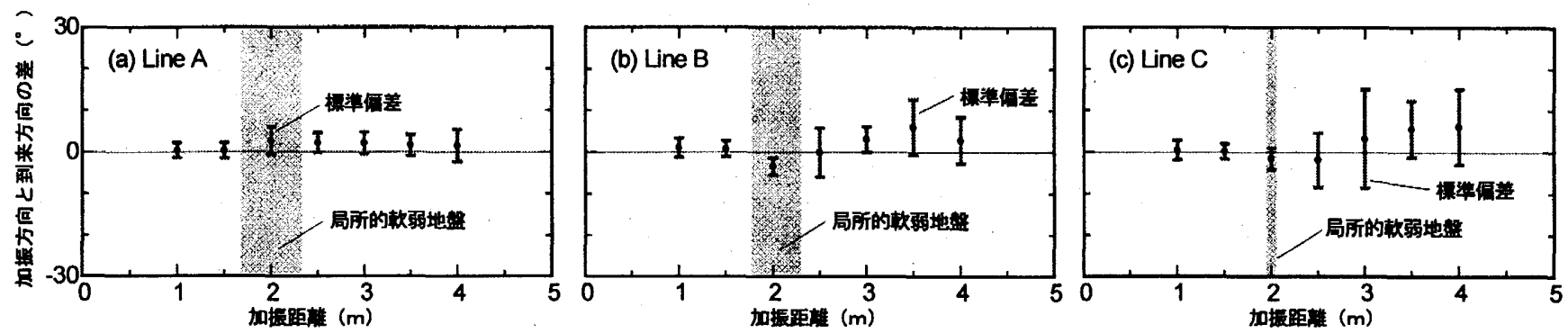

図 14 加振方向と波の到来方向の角度差と加振距離 （Case B， $0.6 \mathrm{~m}$ <波長 $<2.0 \mathrm{~m} ）$

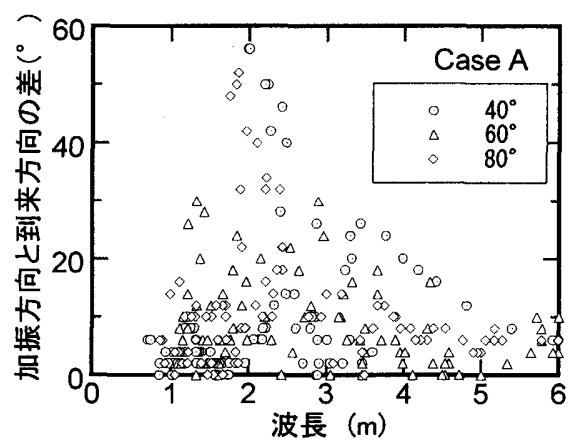

図 15 加振方向と波の到来方向の角度差と波長 (Case A, Case B)

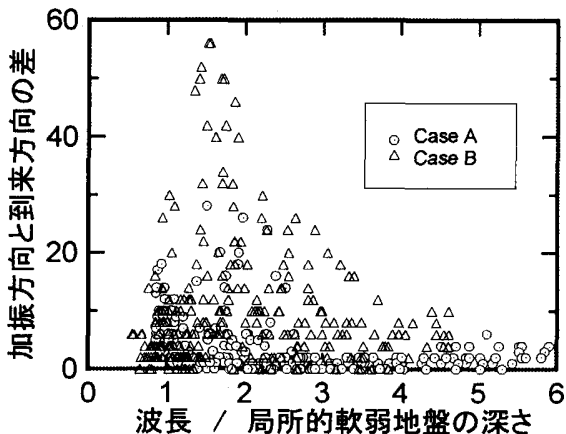

図 16 波の到来方向のばらつく波長と軟弱地盤深さ
方向のばらつきは比較的小さい。ただし、Line B，Cでは、波の到 来方向がややシフトする。加振距離 $3.0 \mathrm{~m}$ および $4.0 \mathrm{~m}$ では、波長 $2 \mathrm{~m}$ 程度以下で到来方向がばらつく。そのばらつきは、Line B，Cで大 きく、Line Aで比較的小さい。

さらに検討するために、全ての加振点における加振方向と波の到 来方向の角度差の平均值と標準偏差を図14に示す。なお、対象とす る波長は、0.6m〜2.0m とした。Line Aの場合、加振距離 $1.0 \mathrm{~m} 、 1.5 \mathrm{~m}$ における加振方向と波の到来方向の角度差および標準偏差は極めて

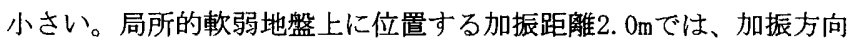
と波の到来方向に平均 $3^{\circ}$ 程度の角度差が生じ標準偏差もやや大き くなる。加振距離 $2.5 \mathrm{~m}$ 以上における加振方向と波の到来方向の角度 差および標準偏差は、加振距離2.0mのそれとほぼ同じである。Line Bの場合、加振距離 $1.0 \mathrm{~m} 、 1.5 \mathrm{~m}$ における加振方向と波の到来方向の 角度差および標準偏差は小さい。局所的軟弱地盤上に位置する加振 距離 $2.0 \mathrm{~m}$ では、加振方向と波の到来方向に平均 $3^{\circ}$ 程度の角度差が 生じるが、標準偏差は加振距離 $1.0 \mathrm{~m} 、 1.5 \mathrm{~m}$ のものと同程度である。 加振距離 $2.5 \mathrm{~m}$ 以上では、加振方向と波の到来方向に平均 $0 \sim 6^{\circ}$ の角 度差が生じ、標準偏差が大きくなる。Line Cの場合、加振方向と波 の到来方向の角度差はLine Bのそれとほほ同様だが、加振距離 $2.5 \mathrm{~m}$ 以上の標準偏差がLine Bより大きい。以上から、加振点が局所的軟 弱地盤上にある場合、波の到来方向は加振方向とやや異なるが、そ のばらつきは比較的小さいことが分かる。また、前節の結果と同様 に、局所的軟弱地盤に対して直交方向から波が入射するよりも、あ る程度の角度をもって波が入射する方が、波の到来方向のばらつき は大きい。

\section{3. 到来方向のばらつく波長と局所的軟弱地盤の深さ}

Case A，Bともに、波長によって波の到来方向のばらつき方は異 なった。波の到来方向のばらつく波長を検討するため、図15に、
Case Aの加振角度 $40^{\circ} ， 60^{\circ} ， 80^{\circ}$ およびCase BのLine A, B,C（加振 距離 $3 \mathrm{~m} ， 4 \mathrm{~m} ）$ における加振方向と波の到来方向の角度差と波長の関 倸を示す。Case Aでは、波の到来方向が波長 $2 \mathrm{~m}$ 程度で最もばらつ くのに対し、Case Bでは、波の到来方向が波長 $1 \mathrm{~m}$ 程度で最もばら つく。このように、波の到来方向のばらつく波長はCase AとCase B で異なる。Case Aの局所的軟弱地盤がCase Bのそれより深いことを 考虑すると、到来方向のばらつく波長は、局所的軟弱地盤の深さと 関係があると考えられる。そこで、波長を局所的軟弱地盤の哚さで 除し、波の到来方向とともに図16に示す。Case A，Bともに、波長 が局所的軟弱地盤の梁さの3 4倍程度より短いと波の到来方向の角 度差が生じ、波長が局所的軟弱地盤の 1.5 倍程度で波の到来方向の 角度差が最も大きくなる。これから、本実験の場合、局所的軟弱地 盤染さは、波の到来方向がばらつく最大波長の $1 / 4 \sim 1 / 3$ 程度、また は波の到来方向が最もばらつく波長の $2 / 3$ 程度と考えられる。

一般的に鉛直点加振源から主にレイリー波が発生し、レイリー波 は波長の $1 / 2$ 程度の樑度の地盤特性を反映すると指摘されている9”。 また、実体波が局所的軟弱地盤に入射すると、特定の周波数で実体 波が增幅したり新たな表面波を生成したりする。これらを考慮する と、到来方向のばらつく波長と局所的軟弱地盤梁さの関係の要因と して、レイリ一波や不整形地盤における実体波の伝播特性の影響が 考えられる。波の到来方向が最もばらつく波長は、局所的軟弱地盤 と周辺地盤のコントラストや、局所的軟弱地盤の平面の大きさや形 状および断面形状にも影響を受けると考えられる。波の到来方向が 最もばらつく波長と局所的軟弱地盤の樑度について、実験および数 值解析で検討を進めていきたい。

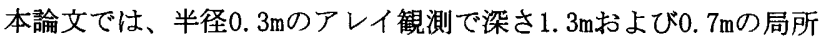
的軟弱地盤を検討した。アレイ観測で評価できる最小波長はアレイ 半径に依存するが、最大波長はアレイ半径のみならず微動レベルや 地盤条件にも依存すると考えられる。そのため、宅地によって、よ 
り大きいアレイ半径が必要になる可能性がある。加振については、 人の跳躍やハンマーの打撃で10 20Hz以上のランダム波が発生す る。その最大波長は、表層 $\mathrm{S}$ 波速度 $100 \mathrm{~m} / \mathrm{s}$ の地盤で $5 \mathrm{~m} \sim 10 \mathrm{~m}$ 程度で あり、一般的な宅地であれば、人の跳躍やハンマーの打撃で表層数 $\mathrm{m}$ 程度を調査対象にできると考えられる。

木造家屋等の小規模建筑物の場合、接地圧による地中応力の主な 分布域は、基礎底面下 $1.5 \sim 2.0 \mathrm{~m}$ の範囲である3”。したがって、提案 手法で表層数 $\mathrm{m} に お け る$ 局所的軟弱地盤の位置を同定し、2 次地盤 調査としてスウェーデン式サウンディング試験等で局所的軟弱地盤 の物性を把握することで、小規模建築物の地盤・基礎のトラブル回 避に貢献できると考えられる。

\section{4.まとめ}

人工的に地表面を加振し、アレイ観測で波の到来方向を計測する ことで、簡便に局所的軟弱地盤の位置を同定する方法を提案した。 その妥当性を検討したところ、以下の結果が得られた。

1）加振点と観測アレイの間に局所的軟弱地盤がある場合、波の到 来方向はばらつく。特に局所的軟弱地盤に対してある程度の角 度をもって波が入射すると、波の到来方向のばらつきは大き い。

2）加振点が局所的軟弱地盤上にある場合、波の到来方向は加振方 向とやや異なるが、ばらつきは比較的小さい。

3）加振点と観測アレイの間に局所的軟弱地盤がない場合、波の到 来方向は概ね加振方向と一致し、そのばらつきは小さい。

4）局所的軟弱地盤媣さは、波の到来方向がばらつく最大波長の $1 / 4 \sim 1 / 3$ 程度、または波の到来方向が最もばらつく波長の $2 / 3$ 程度である。

なお、住宅の不同沈下の要因として、地中のコンクリートの巨塊 なども挙げられる。本論文では局所的軟弱地盤と対象としたが、本 手法は周辺地盤と物性が異なるケースに対しても適用できると考え
られる。さらに、本手法の適用範囲について、さらに検討を進めて いきたい。

\section{謝辞}

本研究は元信州大学工学部社会開発工学科の原田光信君（現在、名古屋市消 防局)によるところが多い。また、元信州大学工学部社会開発工学科の酒井史 紀君、山口伸一郎君、松永光司君、片山寛和君、梅山泰裕君、元信州大学大学 院社会開発工学専攻のZhao Xin 君には、実験に協力いただいた。記して感謝い たします。

\section{参考文献}

1) (財) 住宅リフォーム・紛争処理センター：住宅相談統計年報2004, http:// www.chord.or.jp/shienc/books/soudan_web2004.pdf

2）上野勝代，吉野正绐：欠宿住宅における被害の実態とその特質一欠宿住宅 に扔ける被害構造に関する研究 (第 1 報)，日本建築学会計画系論文報告集， 第359号, pp.95-104, 1986.1

3）日本建築学会：小規模建築物基䃈設計の手引き，1998

4) Nazarian, S. and Stokoe, K. H., II: In site shear wave velocity from spectral analysis of surface wave, Proc. of 8th WCEE, 3, pp.31-38, 1984

5) Tokimatsu, K., Kuwayama, S., Tamura, S., and Miyadera, Y. : Vs Determination from Steady State Rayleigh Wave Method，土留工学会論文報告集，Vol.31， No.2, pp.153-163, 1991, 2

6）時松孝次, 内田明彦，田村修次：木造家屋の震害とレーリー波探查によっ て得られた地盤楼造との関係, 第 8 回日本地震工学シンポジウム論文集, Vol.1, pp.49-54.1990.12

7）林宏一，伊集院博：表面波探查による戸建住宅地盤の 2 次元的調査，シン ポジウム资料「戸建住宅の基礎設計における現状と問題点」, 日本建築学会 棰造委員会基整棬造運営委員会, pp.35-38, 2003.2

8) Capon, J. : High resolution frequency wavenumber spectrum analysis, Proc., IEEE, 57(8), pp.1408-1418, 1969

9）F.E.リチャードjr，J.R.ホールjr，R.D.ウッズ:士と基磷の振動，鹿島出版会， 1975.

（2005年 7 月 4 日原稿受理，2005年 10 月 27 日採用決定） 